\title{
Evaluation of L-thyyoxine therapy in obese children with subclinical hypothyroidism - a pilot study
}

\section{Ocena leczenia L-tyroksyną otyłych dzieci z subkliniczną niedoczynnością tarczycy - badanie pilotażowe}

\author{
'Aleksandra Januszek-Trzciąkowska, ${ }^{1}$ Paweł Matusik, ${ }^{2}$ Katarzyna Klimek, ${ }^{1} E w a$ Małecka-Tendera
}

'Department of Pediatrics, Pediatric Endocrinology and Diabetes, Medical University of Silesia, Katowice, Poland

2Division of Statistics, Department of Instrumental Analysis, Faculty of Pharmacy, Medical University of Silesia, Katowice, Poland

Adres do korespondencji:

Aleksandra Januszek-Trzciąkowska, Klinika Pediatrii, Endokrynologii i Diabetologii Dziecięcej Śląskiego Uniwersytetu Medycznego, ul. Medyków 16, 40-752 Katowice, tel. +48/322023762, fax:+48322023763,

e-mail: olatrz@poczta.onet.pl

Key words: subclinical hypothyroidism, children, obesity, L-thyroxin

Słowa kluczowe: subkliniczna niedoczynność tarczycy, dzieci, otyłość, lewotyroksyna

\section{ABSTRACT/STRESZCZENIE}

Introduction. Subclinical hypothyroidism $(\mathrm{SH})$ is relatively common in obese children and adolescents. It remains controversial whether these patients should be treated with L-thyroxine therapy. The aim of the study was to establish whether L-thyroxine replacement therapy of obese children and adolescents with SH affects BMI, TSH and FT4 levels as well as other metabolic and hormonal variables 3.1 $( \pm 1.1 \mathrm{SD})$ months after withdrawal of the treatment. Material and methods. The study group comprised 30 obese children (18 girls and 12 boys) in the mean age $12.4 \pm 3.5$ years with SH treated with L-thyroxine for $24( \pm 1.3 \mathrm{SD})$ months in whom treatment was consecutively withdrawn, and the control group of 33 obese patients (17 girls and 16 boys) in the mean age $13.7 \pm 2.5$ years, with normal function of the thyroid gland. Hormonal (TSH, FT4, FT3, insulin, leptin, adiponectin) parameters, lipid profile, OGTT and TNF- $\alpha$ were compared between the groups. Results. Leptin level and HDL cholesterol in obese children with SH treated with L-thyroxine were statistically significantly higher after the treatment withdrawal than in obese children with normal function of the thyroid gland, while other hormonal, glucose and lipid parameters were not statistically different. In about $50 \%$ of obese children with SH TSH levels remained over the normal range but none of the patients converted to overt hypothyroidism. There was no difference between BMI change between treated and untreated children. Conclusion. Treatment with L-thyroxine of obese children with SH had no effect on their weight loss as their final BMI was not significantly different than in obese controls with normal thyroid function. Pediatr. Endocrinol. 12/2013;2(43): 21-26. 
Wstęp. U otyłych dzieci i młodzieży subkliniczna niedoczynność tarczycy (SNT) występuje stosunkowo często i leczenie jej substytucyjnymi dawkami L-tyroksyny nie jest w pełni uzasadnione. Celem pracy było zbadanie, czy terapia L-tyroksyną wpływa na BMI, stężenie TSH, hormonów tarczycy oraz na inne parametry hormonalne i metaboliczne w 3.1( $\pm 1.1 \mathrm{SD})$ miesiące po jej zaprzestaniu. Material i metody. Badaniem objęto 30 otyłych dzieci (18 dziewcząt i 12 chłopców) w wieku 12.4 \pm 3.5 SD lat, u których rozpoznano SNT i na 24 ( $\pm 1.3 \mathrm{SD}$ ) miesiące włączono lecenie L-tyroksyną. Po odstawieniu leczenia porównano stężenia hormonów (TSH, FT4, FT3, insuliny leptyny, adiponektyny), profil lipidowy, test doustnego obciążenie glukozą, i stężenia TNF- $\alpha$ pomiędzy grupą badana a grupą kontrol-

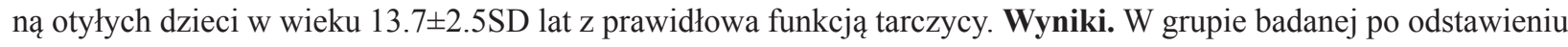
leczenia stwierdzono istotnie wyższe stężenia leptyny i HDL-cholesterolu w porównaniu do grupy kontrolnej. Pozostałe parametry nie różniły się istotnie pomiędzy grupami. Około 50\% dzieci z SNT miało nadal stężenie TSH pomiędzy 5 a 10 mIU/l, lecz u żadnego z nich nie wystąpiła jawna niedoczynność tarczycy. Wnioski. Leczenie L-tyroksyną otyłych dzieci z SNT nie miało wpływu na ich masę ciała, ponieważ ich ostateczne BMI nie różniło się istotnie od otyłych dzieci z prawidłową funkcją tarczycy. Endokrynol. Ped. 12/2013;2(43):21-26.

\section{Introduction}

Subclinical hypothyroidism ( $\mathrm{SH}$ ) is defined as serum TSH level above the upper limit of the reference range when serum FT4 concentration is within its reference range [1]. This condition is quite common in adulthood with worldwide prevalence from 4 to $10 \%$ in general population $[1,2]$. In elderly its prevalence is estimated on 7 to $26 \%$ [3]. In children's population the SH prevalence seems to be lower [4], but in obese children and adolescents it was reported to be as high as $22 \%$ [5]. Most studies demonstrate that TSH elevation in obese adults and children is rather moderate and may be reversed with the weight loss [6-8].

It remains controversial whether patients with SH should be treated with replacement L-thyroxine therapy. Meta-analysis of the publications on SH in adults revealed little benefit of the therapy in terms of hypothyroid symptoms, serum lipid concentrations, cardiac function and quality of life $[4,9]$. In children the spontaneous evolution of $\mathrm{SH}$ was reported in some studies [10-12]. It was described as a remitting process with a low risk of evolution toward over hypothyroidism. Most of the patients reverted to euthyroidism or remained SH. There is a lack of controlled pediatric studies describing the outcome of SH children treated with L-thyroxine versus those receiving placebo or no therapy. Some data indicates that moderately increased TSH in obese children normalized during weight loss and $\mathrm{SH}$ seems to be rather a consequence of obesity than a cause of obesity [8].

The aim of this study was to establish whether L-thyroxine treatment of obese children and adolescents with SH affects TSH and FT4 levels as well as other metabolic and hormonal variables after withdrawal of the treatment.

\section{Patients and methods}

This was a retrospective study performed in obese children and adolescents attending the Obesity Outpatients Department of the Upper-Silesian Medical Center of Child's Health in Katowice. The study group (group A) comprised 30 obese children (18 girls and 12 boys) in the mean age of $12.4 \pm 3.5$ SD years, in whom subclinical hypothyroidism was diagnosed at the evaluation studies at the mean age of $10,4 \pm 3.3$ SD years. Obesity was defined according to the body mass index (BMI) exceeding 97th percentile using the definition of the International Task Force of Obesity in Childhood [13]. The exclusion criteria were goiter and other abnormalities in thyroid ultrasonography, presence of thyroid autoantibodies, concomitant therapy with lithium salts, antiepileptic therapy, glucocorticoids or iodine containing drugs as well as former neck radiation therapy. SH was confirmed on the base of elevated TSH level (between 5-10 mU/l) and normal FT4 level (between 0,8-2,4 ng/dl). All these patients were treated with L-thyroxine $(1-2 \mu \mathrm{g} / \mathrm{kg} /$ day) for $24( \pm 1.3 \mathrm{SD})$ months. TSH and FT4 serum levels were confirmed to be within reference ranges during all the treatment period. In all patients the treatment was withdrawn and TSH, FT4, FT3, lipid profile, OGTT, insulin, leptin, adiponectin, TNF- $\alpha$ were measured after 3.1 $( \pm 1.1 \mathrm{SD})$ months of the follow-up period. Plasma leptin levels were measured using TECO ELISA assay kit for human Leptin (so-called Sandwich-Assay) using two specific and high affinity monoclonal antibodies. The analytical sensitivity of the assay yields $0,2 \mathrm{ng} / \mathrm{ml}$. Adiponectin was measured using TECO Total Human Adiponectin ELISA kit, (so-called Sandwich-Assay) using two specific and high affinity monoclonal 
antibodies. The lower detection limit was $0,6 \mathrm{ng} / \mathrm{ml}$. TNF alfa levels were measured using Human TNF alfa HS ELISA kit. TSH, FT4 and FT3 levels were determined by ELISA kits.

The control group (Group B) consisted of 33 obese patients (17 girls and 16 boys) in the mean age $13.7 \pm 2.5$ years, with normal function of the thyroid gland. Difference in age and BMI between the two groups at the study point was statistically insignificant ( $p>0.05)$. In all children the same auxiological, lipid and hormonal parameters were measured at the study point.

Data analyses were performed using the STATISTICA version 8. [www.statsoft.com, Statsoft, Inc.2003]. The normality of distributions was verified with Shapiro-Wilk test and by histograms. The t-test for independent samples was used to identify differences between parameters for normal distributions (TSH1 and leptin) or the Mann-Whitney U test was used when data were not normally distributed or variances were not homogeneous (HDL). P-value $<0.05$ was considered statistically significant.

The study was performed according to the guidelines of the Helsinki Declaration on human experimentation and was approved by the Ethics Committee of Medical University of Silesia. An informed consent was obtained from every subject or/and parent or guardian.

\section{Results}

In the study group BMI did not change significantly as compared to the time of referral to the Obesity Clinic $(31.4 \pm 5.8 \mathrm{SD}$ vs $31.6 \pm 5.7 \mathrm{SD})$. In the control group BMI increased insignificantly from $31.9 \pm 5.8 \mathrm{SD}$ to $33 . \pm 4.9 \mathrm{SD}$. The difference between the study and the control groups was not statistically significant at the time of referral as well as at the time of the study point. In the study group TSH levels measured after $3.1( \pm 1.1 \mathrm{SD})$ months of

Table I. Anthropometric and laboratory characteristics of the study group (Group A) and the control group (group B) 3( \pm 1 ) months after L-thyroxine therapy withdrawal

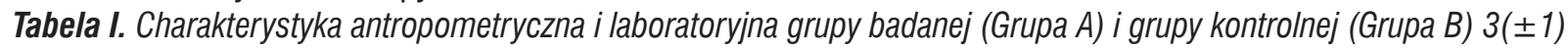
miesięcy po zakończeniu terapii L-tyroksyną

\begin{tabular}{|l|c|c|c|}
\hline & $\begin{array}{c}\text { Group A; N-30 } \\
\text { (18 girls and 12 boys) }\end{array}$ & $\begin{array}{c}\text { Group B; N=33 } \\
\text { (17 girls and 16 boys) }\end{array}$ & p \\
\hline Mean age (years) & $12.4 \pm 3.5$ & $13.7 \pm 2.5$ & NS \\
\hline BMI (kg/m²) & $31.6 \pm 5.7$ & $33.2 \pm 4.9$ & NS \\
\hline TSH (mlU/l) & $5.4 \pm 1.2$ & $2.3 \pm 0.8$ & $<0.001$ \\
FT4 (ng/dl) & $1.2 \pm 0.2$ & $1.1 \pm 0,1$ & NS \\
FT3 (pg/ml) & $2.9 \pm 0,7$ & $2.7 \pm 0,7$ & NS \\
Glucose 0' (mg/dl) & $88.2 \pm 10.3$ & $88.71 \pm 10.6$ & NS \\
Glucose 120'(mg/dl) & $115.0 \pm 21.8$ & $116.9 \pm 30.2$ & NS \\
Insulin 0'(mlU/ml) & $19.05 \pm 1 ., 93$ & $23.19 \pm 42.99$ & NS \\
Insulin 120'(mlU/ml) & $105.77 \pm 77.39$ & $105.82 \pm 112.32$ & NS \\
Cholesterol (mg/dl) & $191.21 \pm 38.62$ & $181.03 \pm 33.92$ & NS \\
TG (mg/dl) & $154.34 \pm 80,43$ & $153.00 \pm 66.74$ & NS \\
HDL (mg/dl) & $48.90 \pm 11.87$ & $44.12 \pm 7.61$ & 0.04 \\
LDL (mg/dl) & $117.73 \pm 25.51$ & $138.32 \pm 43.68$ & NS \\
Leptin (ng/ml) & $40.13 \pm 22.51$ & $26.94 \pm 17.01$ & 0.013 \\
Adiponectin (ng/ml) & $4.59 \pm 2.32$ & $5.24 \pm 2.65$ & NS \\
TNF alfa (pg/ml) & $0.81 \pm 0.39$ & $0.93 \pm 0.63$ & NS \\
\hline
\end{tabular}


the follow-up period post L-thyroxine withdrawal remained below $5 \mathrm{mIU} /$ in $14(47 \%)$ patients. In 16 (53\%) children TSH levels were stabilized over the normal range: in $13(43 \%)$ between $5-7 \mathrm{mIU} / 1$. and in $3(10 \%)$ between $7-10 \mathrm{mIU} / 1$. None of them had hyperthyrotropinemia $>10 \mathrm{mIU} / 1$ or FT4/FT3 below normal range after L-thyroxine withdrawal.

The mean TSH level in obese children with $\mathrm{SH}$ (group A) after L-thyroxine therapy withdrawal was statistically significantly higher than in group B (table I). There were no differences in FT4 and FT3 levels between study and control group. FT4 levels remained within a normal range $(0.8-2.4 \mathrm{ng} / \mathrm{dl})$ as well as FT3 levels $(1.5-4.0 \mathrm{pg} / \mathrm{ml})$.

There were no differences in glucose levels and insulin levels between study group and control group in OGGT test. Mean HDL level in obese children with SH was statistically significantly higher $(48.9 \pm 11.9 \mathrm{mg} / \mathrm{dl})$ than in obese children with normal function of the thyroid gland $(44.1 \pm 7.3 \mathrm{mg} /$ dl) $(p<0.05)$ (Fig. 1). No differences in total cholesterol, LDL and TG levels between study group and control group were noted. Mean leptin levels in obese children with SH (Group A) was $40.13 \pm 22.51$ $\mathrm{ng} / \mathrm{ml}$ and was statistically significantly higher than in obese children with normal function of the thyroid gland (Group B) $(p<0.01)($ Fig.2). There were no significant differences in adiponectin levels and TNF- $\alpha$ level between the study group and the control group.

\section{Discussion}

Moderately elevated TSH levels were frequently found in obese subjects [6-8]. The positive correla-

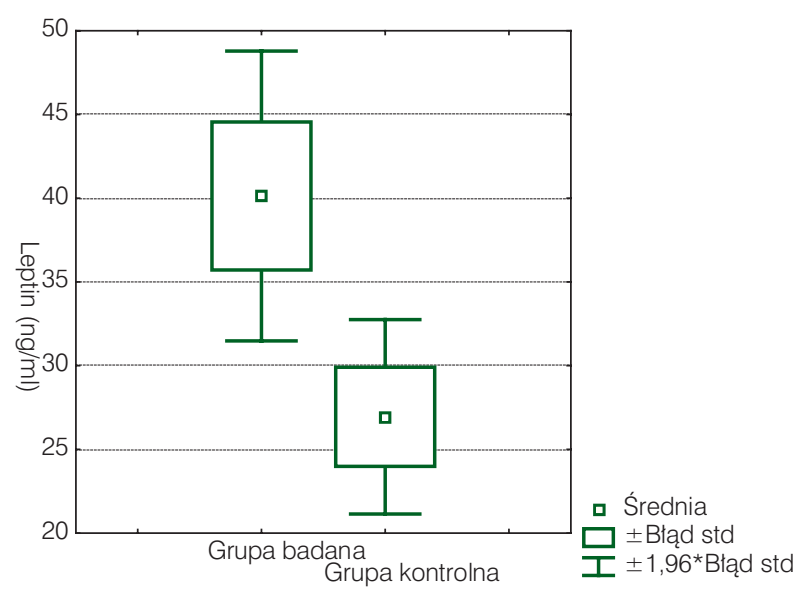

Fig. 1. Leptin levels in the study group vs control group Ryc. 1. Stężenia leptyny w grupie badanej vs grupa kontrolna tion between TSH and BMI in obese patients was noticed by some authors $[6-8,14]$ and the correlation between serum leptin and serum TSH levels was also described by some [14] but not confirmed by the others [8]. In our data leptin levels in obese children with SH treated with L-thyroxine were statistically significantly higher than in obese untreated children with normal thyroid function. Our results may suggest that TSH production is regulated by leptin. Several mechanisms of hiperthyrotropinemia in obesity were considered such as increased leptin-mediated production of pro-TRH, impaired feedback due to smaller number of hypothalamic T3 receptors or changes in peripheral deiodinase activity [7]. We may also speculate that higher leptin in obese children with $\mathrm{SH}$ were an effect of the higher body fat mass compared to obese children with normal thyroid function. On the other hand adiponectin levels were not statistically different between the two groups.

Abnormalities in thyroid function and TSH secretion in obese persons are most often reversible, because weight loss leads to normalization of elevated TSH levels. Therefore some authors suggest that hiperthyrotropinemia is more a consequence that a cause of obesity $[8,15]$. However in about a half of our patients TSH decreased to normal and in the other half remained within 5.0-10.0 mIU/1. This changes were independent of the fact that their BMI did not significantly decrease during the study period.

Obese individuals are in high risk of developing metabolic complications such as impaired glucose tolerance, hypertension and dyslipidemia [16,17]. Some data confirmed that obese children with

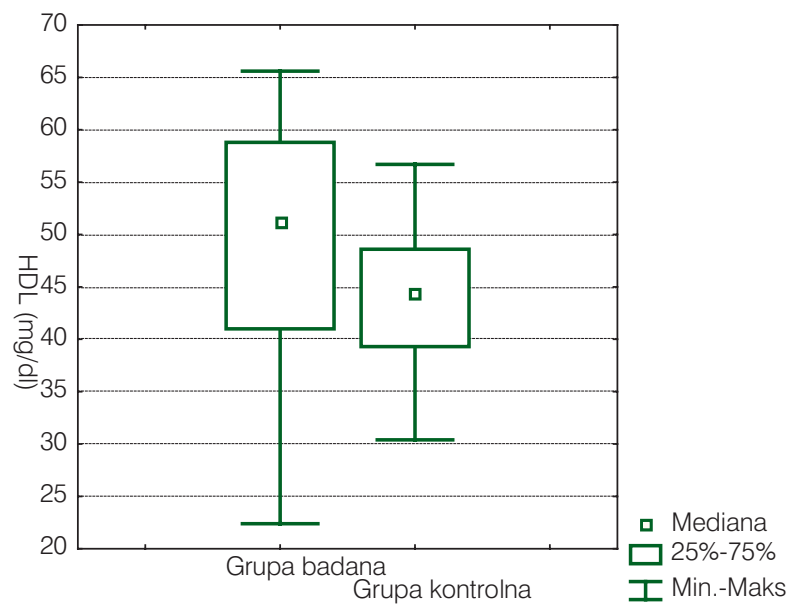

Fig. 2. HDL levels in the study group vs control group Ryc. 2. Stężenia HDL w grupie badanej vs grupa kontrolna 
subclinical hypothyroidism had a higher incidence of hipertrigliceridemia than obese children with normal function of the thyroid gland [5]. Elevated total cholesterol/HDL cholesterol, elevated LDL/ HDL cholesterol, and hipertrigliceridemia were described in women with SH [18]. In our study total cholesterol and TG levels were not different between L-thyroxine treated and untreated groups but HDL level were significantly higher in obese children with SH than in obese children with normal function of thyroid. Whether this was an effect of Lthyroxin treatment remains questionable as the drug was withdrawn several months before. Therapy also did not influence TNF- $\alpha$, insulin and glucose levels as there were no significant differences in these parameters between the study and control group.

The question whether obese patients with $\mathrm{SH}$ should be treated with a replacement of L-thyroxine is controversial. Natural course of SH has been characterized by frequent spontaneous normalization of TSH levels, whereas in $12 \%$ of patients progression to overt hypothyroidism was observed after 2-years of the follow-up period [10]. Most authors recommend treatment when TSH levels are greater than $10 \mathrm{uIU} / \mathrm{ml}$. Asymptomatic patients with TSH levels between 4.5 and $10 \mathrm{uIU} / \mathrm{ml}$ should have the test repeated every 6 to 12 months. Available data do not support a benefit of early treatment, but in patients with symptoms of hypothyroidism with TSH concentration between 4.5-10.0 uIU/ml such a treatment is suggested to see if the symptoms improve [1].
Our study has several limitations. First of all it was a retrospective one and so we could not compare the dynamics of hormonal parameters during the course of treatment. Many children were also lost for the follow up after the L-thyroxine withdrawal so the study group was relatively small. The change in BMI in all the children included was also very modest so we could not correlate the BMI dynamics with the measured parameters. On the other hand we showed that L-thyroxine treatment of obese children with $\mathrm{SH}$ and negative antythyroid antibodies does not seem to change the natural course of thyroid dysfunction and does not affect their BMI. The study needs to be confirmed on a larger group of patients.

\section{Conclusions}

1. Leptin level and HDL cholesterol in obese children with SH treated with L-thyroxine were statistically significantly higher after the treatment withdrawal than in obese children with normal function of the thyroid gland, while other hormonal, glucose and lipid parameters were not statistically different.

2. In $53 \%$ of obese children with subclinical hypothyroidism TSH levels remained over the normal range after withdrawal of L-thyroxine replacement therapy however none of them converted to overt hypothyroidism.

3. Final BMI of obese children with SH treated with L-thyroxine was not significantly different than in obese controls with normal thyroid function.

\section{REFERENCES/PIŚMIENNICTWO}

[1] Surks M.I., Otriz E., Daniels G.H. et al.: Subclinical thyroid disease. Scientific review and guidelines for diagnosis and management. JAMA, 2004:291, 228-238.

[2] Chu J.W., Crapo L.M.: The treatment of subclinical hypothyroidism is seldom necessary. J. Clin. Endocrinol. Metab., 2001:86, 45914599.

[3] McDermott M., Ridgway E.C.: Subclinical Hypothyroidism is mild thyroid failure and should be treated. J. Clin. Endocrinol. Metab., 2001:86, 4585-4590.

[4] Wu T., Flowers J.W., Tudever F. et al.: Subclinical thyroid disorders and cognitive performance among adolescents in the United States. BMC Pediatr., 2006:6, 12.

[5] Shalitin S., Yackobovitch-Gacan M., Philip M.: Prevalence of thyroid function in obese children and adolescents before and after weight reduction and its relation to other metabolic parameters. Horm. Res., 2009:71, 155-161.

[6] Nymes A., Jorde R., Sundsfjord J.: Serum TSH is positively associated with BMI. Int. J. Obes. (Lond), 2006:30, 100-105.

[7] Knudsen N., Laurberg P., Rasmussen LB. et al.: Small differences in thyroid function may be important for body mass index and the occurrence of obesity in the population. J. Clin. Endocrinol. Metab., 2005:90, 4019-4024.

[8] Reinehr T., Soussa G., Andler W.: Hyperthyreotropinemia in obese children is reversible after weight loss and is not related to lipids. J. Clin. Endocrinol. Metab., 2006:91, 3088-3091.

[9] Villar H.C., Saconato H., Valente 0. et al: Thyroid hormone replacement for subclinical hypothyroidism. Cochrane Database. Syst. Rev., 2007:18, CD003419. 
[10] Wasniewska M., Salerno M., Cassio A. et al.: Prospective evaluation of the natural course of idiopathic subclinical hypothyroidism in childhood and adolescence. Eur. J. Endocrinol., 2009:160, 417-421.

[11] Cerbone M., Bravaccio C., Capalbo D. et al: Linear growth and intellectual outcome in children with long-term idiopathic subclinical hypothyroidism. Eur. J. Endocrinol., 2011:164, 591-597.

[12] Kaplowitz P.B.: Subclinical hypothyroidism in children: normal variation or sign of a failing thyroid gland? Int. J. Pediatr. Endocrinol., 2010:2010, 1-8.

[13] Cole T.J., Bellizzi M.C., Flegal K.M. et al.: Establishing a standard definition for child overweight and obesity world-wide international survey. BMJ, 2000:320, 1240-1243.

[14] lacobellis G., Bibaudo M.C., Zappaterreno A. et al.: Relationship of thyroid function with body mass index, leptin, insulin sensitivity and adiponectin in euthyroid obese women. Clin. Endocrinol., 2005:62, 487-491.

[15] Grandone A., Santoro N., Coppola F. et al.: Thyroid function derangement and childhood obesity: an Italian experience. BMC Endocrine Disorders, 2010:10, 8-12.

[16] Przybysz M., Rymaszewska-Syryca D., Nastaj M., Milchert M. et al.: Ocena częstości występowania zespołu metabolicznego u dzieci z otyłością prostą. Endokrynol. Ped., 2009:8, 45-54

[17] Zatorska-Karpuś, Pac-Kożuchowska E., Kozłowska M.: Typ otyłości a parametry przemiany lipidowej u dzieci. Endokrynol. Ped., 2009:8, 55-60.

[18] Luboshitsky R., Aviv H., Herer P. et al.: Risk factors for cardiovascular disease in women with subclinical hypothyroidism. Thyroid, 2002:12, 421-425. 